\title{
The Effect of Extensive Reading on Students' Reading Achievement Of Senior High School
}

\author{
Author \\ Eka Mardiana, Nur Hidayat \\ Correspondence \\ STKIP Bina Insan Mandiri Surabaya \\ ekayeliz@gmail.com,nurhidayat@stkipbim.ac.id
}

\begin{abstract}
:
The aim of this study was to investigate the effects of extensive reading on students' reading achievement for senior high school grade $\mathrm{X}$. The extensive reading was an alternative method in the teaching reading to make the students fun and easy to get the meaning of texts from many sources. The subjects were 27 students at grade $\mathrm{X}$ in the academic year 2018/2019. The researcher applied by using in a quasi-experimental design using a quantitative approach. The instrument of this research used pre-questionnaires, test and observation. The technique of analyzing data was applied by using a paired sample t-test from the Statistical Package for the Social Sciences 22 (SPSS22). The result of the analysis showed that the mean of the pre-test was 79, 85 and the mean of post-test was 85,56 . The mean score of posttest was higher than pretest in experimental class who were taught by extensive reading. It concluded that the implementation of the extensive reading can give positive effects to the students. It was supported by the result of observation showed that the students were enthusiastically to answer the question, many vocabularies, fun, enjoyable, easy to understand the meaning of the texts and more active in the teaching learning.
\end{abstract}

Keywords: Extensive Reading, reading comprehension, Teaching Method.

\section{Introduction}

Reading skill is the most important skill to get more information. The students in the school always get the lesson of reading start from playgroup, kindergarten, elementary school, junior high school, senior high school until university. The students get an English lesson as a foreign language in the school. The objective of teaching reading is to improve the reading comprehension of students. The students are able to read well and get more information.

According to Anderson (2003) "Reading is a fluent process of readers combining information from a text and their own background knowledge to build meaning". One way of the best ways to take pleasure the students in learning rather than feeling that learning English is hard work and something that they have to do is the meaning of reading (Prowse, 2003; Day, 2015). Reading in English as a foreign language is an essential skill to collect information. Reading English texts can give more benefits for the reader to increase their skills in English as a foreign language, especially in reading comprehension.

The reading ability of students is affected by many factors. The factors are internal and external.
Received: 05 Agustus 2019. Accepted: 22 Agustus 2019

Internal factor is factors from inside a person. Talent, mood, interest, motivation and so on are the internal factors. The external factor is factors from outside a person. The environment, friends, parents, facilities, teachers and teaching methods are the external factors. The students have low ability in reading comprehension and feel bored while they are in the reading activity with many tasks. That can be caused by methods of teaching-learning. So, the teachers have to do innovation and up to date in methods of teaching reading.

The teachers can use many methods that can be applied to improve students' reading comprehension. The methods are skimming, scanning, intensive reading and extensive reading. The extensive reading as a method to teach reading may be thought in many purposes because the extensive reading is arbitrary or free reading for pleasure. The students need more strategies to help them in reading comprehension, so they can be easy to understand the meaning of the texts with their own interesting.

Meng (2009) said that an effective and pleasurable way for the students to learn to read English as a foreign language as an alternative to the intensive reading course is the extensive reading 
program. Bamford \& Day (2003) stated that an approach to language teaching in which learners read a lot of easy material in the new language is extensive reading. Extensive reading is a method of teaching reading to make the student happy in this lesson as a foreign language and easy to understand the meaning of the text. The students will be interested in this lesson if the teachers have an idea to engage them in this lesson.

\section{Objective of the Study}

Based on the research question above the objective of the study is to investigate the effects of extensive reading to reading comprehension in English lesson by using extensive reading as a teaching method for senior high school grade $\mathrm{X}$.

\section{Method}

The design in this research was a quasiexperimental design with choosing one group pretest-posttest or single-group pretest-posttest design as a kind of research design that involved the collection of data and only used one variable.

\section{Population and Sample}

The population was the students of grade $\mathrm{X}$ in the second semester from one of senior high schools in Surabaya East Java. There were four classes: IPA1, IPA2, IPA3, and IPS. Totaly the students of grade $\mathrm{X}$ was 107 . The sample of the research was arranged by simple random sampling. The sample was one class of 4 classes of the second semester; they were 27 students of X-IPA3. It consisted of 16 female and 11 male in the classroom. The students' native language was Javanese and they were learning English as a foreign language. They had attended two days a week and $2 \times 45$ minutes for each meeting in the English lesson.

\section{Instrument}

In this study, the researcher used pre-questionnaire to know the opinion of the students about reading in English lesson in the preliminary study before doing the pretest. Pre-questionnaires consists of five questions multiple choice and three open-ended questions. In the multiple-choice have three choices; there was yes, sometimes, and no. The aim of the open-ended question was to know the reason for the students about reading in English. The researcher used tests and observation as a data collection. The test was done twice: pretest and posttest to measure the reading achievement of the students. The observation was done by the researcher to know the effects of extensive reading to the students in the class.

\section{Data Analysis}

The data analysis used quantitative data. The technique of quantitative data analysis is the process of data by numbers. In this research, after data pretest and posttest collected in the file then the result of the data to be analyzed by using the Statistical Package for the Social Sciences 22 (SPSS 22). A Paired Sample t-test was used to measure gain scores of both groups from pre-and posttesting. The data were used to find out the effects of extensive reading on student's reading comprehension.

\section{Findings}

In the preliminary study, the researcher administered the pre-questionnaire sheet and the reading test. The aim of the pre-questionnaire sheet is used to know the opinion of the students about English lesson in the previous learning before doing the pretest. The pre-questionnaires were modified form Hidayat (2016) questionnaires.

Table 1 the Result of Pre-Questionnaires

\begin{tabular}{|c|c|c|c|}
\hline Questionnaire & Answer & Result & $\begin{array}{c}\text { Percentag } \\
\text { e }\end{array}$ \\
\hline \multirow{3}{*}{$\begin{array}{l}\text { Do you like } \\
\text { English } \\
\text { lesson? }\end{array}$} & Yes & 6 students & $22,22 \%$ \\
\hline & $\begin{array}{c}\text { Sometime } \\
\mathrm{s}\end{array}$ & $\begin{array}{c}17 \\
\text { students }\end{array}$ & $62,96 \%$ \\
\hline & No & 4 students & $14,81 \%$ \\
\hline \multirow{3}{*}{$\begin{array}{c}\text { Do you like } 4 \\
\text { skills in } \\
\text { teaching } \\
\text { English? }\end{array}$} & Yes & $\begin{array}{c}13 \\
\text { students }\end{array}$ & $48,15 \%$ \\
\hline & $\begin{array}{c}\text { Sometime } \\
\mathrm{s}\end{array}$ & 8 students & $29,63 \%$ \\
\hline & No & 6 students & $22,22 \%$ \\
\hline \multirow{3}{*}{$\begin{array}{l}\text { Do you like } \\
\text { reading } \\
\text { English? }\end{array}$} & Yes & $\begin{array}{c}10 \\
\text { students }\end{array}$ & $37,04 \%$ \\
\hline & $\begin{array}{c}\text { Sometime } \\
\mathrm{s}\end{array}$ & $\begin{array}{c}12 \\
\text { students }\end{array}$ & $44,44 \%$ \\
\hline & No & 5 students & $18,52 \%$ \\
\hline \multirow{3}{*}{$\begin{array}{l}\text { Do you get } \\
\text { trouble to } \\
\text { understand the } \\
\text { text? }\end{array}$} & Yes & 9 students & $33,33 \%$ \\
\hline & $\begin{array}{c}\text { Sometime } \\
\mathrm{s}\end{array}$ & $\begin{array}{c}17 \\
\text { students }\end{array}$ & $62,96 \%$ \\
\hline & No & 1 student & $3,70 \%$ \\
\hline $\begin{array}{l}\text { Do you get } \\
\text { trouble to }\end{array}$ & Yes & $\begin{array}{c}11 \\
\text { students }\end{array}$ & $40,74 \%$ \\
\hline
\end{tabular}




\begin{tabular}{|c|c|c|c|c|c|c|c|c|c|}
\hline \multirow{2}{*}{$\begin{array}{l}\text { collect } \\
\text { information } \\
\text { from the text? }\end{array}$} & \multirow{2}{*}{$\begin{array}{l}\text { Sometime } \\
\qquad \mathrm{s} \\
\text { No }\end{array}$} & \multirow{2}{*}{$\begin{array}{c}14 \\
\text { students } \\
2 \text { students }\end{array}$} & $51,85 \%$ & \multicolumn{3}{|c|}{ Descriptive Statistics } & & & \\
\hline & & & $7,41 \%$ & & & & & & Std. \\
\hline \multirow{2}{*}{\multicolumn{4}{|c|}{$\begin{array}{l}\text { The result of pre-questionnaires showed that } \\
\text { ny students feel difficult in understanding } \\
\text { glish text. They have low motivation in reading } \\
\text { glish text and most of them stiil have trouble in }\end{array}$}} & & $\mathrm{N}$ & Min & Max & Mean & Dev. \\
\hline & & & & $\begin{array}{l}\text { Pre-test } \\
\text { Valid N } \\
\text { (listwise) }\end{array}$ & 27 & 44 & 100 & 79,85 & $\begin{array}{l}12,27 \\
5\end{array}$ \\
\hline
\end{tabular}

Table 2. The result of Pre and Post-test.

\begin{tabular}{|c|c|c|}
\hline \multirow{2}{*}{ Initial } & \multicolumn{2}{|c|}{ Score } \\
\cline { 2 - 3 } Name & Pre-test & Post-est \\
\hline U & 44 & 70 \\
\hline H & 67 & 70 \\
\hline A & 67 & 75 \\
\hline G & 72 & 75 \\
\hline I & 72 & 80 \\
\hline R & 72 & 80 \\
\hline T & 72 & 80 \\
\hline V & 72 & 80 \\
\hline C & 74 & 80 \\
\hline B & 78 & 80 \\
\hline E & 78 & 85 \\
\hline L & 78 & 85 \\
\hline M & 78 & 90 \\
\hline O & 78 & 90 \\
\hline X & 78 & 90 \\
\hline Z & 78 & 90 \\
\hline S & 83 & 90 \\
\hline D & 89 & 90 \\
\hline J & 89 & 90 \\
\hline AB & 89 & 90 \\
\hline F & 94 & 90 \\
\hline K & 94 & 90 \\
\hline Q & 94 & 90 \\
\hline AA & 94 & 100 \\
\hline Y & 100 & 100 \\
\hline AC & 100 & 100 \\
\hline & & \\
\hline
\end{tabular}

Based on table 3, the output descriptive statistic represented that the subject was 27 students in the experimental class. The minimum score was 44 and the maximum score was 100 . The mean of the pretest score was 79,85. It indicated that the students reading comprehension score are still low.

Table 4. Mean of Post-test

\begin{tabular}{|c|c|c|r|r|r|}
\hline & $\mathrm{N}$ & Min & Max & Mean & Std. De \\
\hline Post-test & 27 & 70,00 & 100,0 & 85,555 & 8,2431 \\
$\begin{array}{c}\text { Valid N } \\
\text { (listwise) }\end{array}$ & 27 & & 0 & 6 & 0 \\
\hline
\end{tabular}

Based on Table 4 above, the output descriptive statistic in posttest pointed that the subject was 27 students in the experimental class. The minimum score was 70 and the maximum score was 100 . The mean of the pretest score was 85,56. The score of the students was better after giving the treatments. It means that the extensive reading improve students' reading achievement.

Table 5 result of Paired sample test

\begin{tabular}{|c|c|c|c|}
\hline $\mathrm{N}$ & $\begin{array}{c}\text { Mean Pre- } \\
\text { test }\end{array}$ & $\begin{array}{c}\text { Mean Post- } \\
\text { test }\end{array}$ & $\begin{array}{c}\text { Sig. 2 } \\
\text { Tailed }\end{array}$ \\
\hline 27 & 79,85 & 85,56 & 0,045 \\
\hline
\end{tabular}

Based on the Table 5 above showed that the significant value was 0,045 less than $0,05(\mathrm{p}<0,05)$. It indicated that extensive reading significantly give positive effects on students' reading achievement at senior high school grade X.

\section{The Result of Observation the Class}

The Table 2 showed the students' pre and post-test score. Most of them experience enhancement from pre-test to post test.

In this study, the researcher did observation during teaching-learning in the class. The researcher asked the students about the extensive reading and the students gave the feedbacks.

Student X: "The extensive reading helped me to understand the point of the text, although I didn't like reading. I can collect new vocabularies such as 
defiant, siege, naval, air bombardment and weapony".

Student O: "I thought that reading was bored activity but it was fun with extensive reading because I can read well".

Student B: "I can do the questions well because I got the meaning of the text".

The researcher looked the students' enthusiastic when asking the question in the class. The students were active to ask when they did not understand.

Student S: "Miss, I can answer that".

Student AC, $E, L, M, X, Z, D, Q$ : "Miss, I am....I am".

Student L: "Miss, may I ask?

Researcher: "Yes, of course."

Student L: "In the story of the battle of Surabaya said that the Indonesian troops and the leaders of militia angered because they felt betrayed, but I do not know the meaning of felt betrayed?".

Researcher: "Well, I will explain the meaning of felt betrayed. When you have a girlfriend and she went with the other boy in your behind. In the Indonesia language means merasa dikhianati".

The students felt fun and enjoy after reading the text then discuss together with game and practice. At the last meeting, the researcher gave a text reading. The legend of Issumboshi was as the posttest of reading comprehension. The students were enthusiastic to read the text. After that, the researcher showed the video of Issumboshi to make the circumstance of class fantastic.

Student O: "This was fun for me because it made me unsleeping in the teaching-learning".

Student Z: "I can enjoy in many varieties of reading texts with extensive reading. So, I can read well, thank you".

\section{Discussion}

The result of data above reported that there was positive effects using extensive reading. It was supported by the fact the mean of the students' score in the pre-test was $79, .85$ then increased to 85,56 . The number of students who took the test was 27 students in the class. It relevant with the statement of Meng (2009) who explained that extensive reading is one of alternative ways to improve students' reading comprehension.

From the result of observation found that the students were active in learning reading comprehension through extensive reading. The students got new vocabularies from reading many texts that were supported by Ferdila (2014), the extensive reading gave five benefits, :building students' perspective that reading is an interesting activity, creating an enjoyable learning circumstance, helping students in developing a large of vocabulary, improving students' reading comprehension, and increasing students' motivation in reading. Mikeladze (2014) pointed out that extensive reading contributes to students' improvement in reading fluency and vocabulary, and providing enjoyable reading experience. The other positive effects are an enthusiast of students, to be active to ask and quest during teachinglearning. The English teacher also agreed that the method was suitable to use in the class because the method made the students being active and understand the text. Morgado (2009) stated that the students' perception of extensive reading was very positive.

Based on the explanation above, it could be concluded that the result of the research showed that the implementation of the Extensive Reading was the success of the students' ability in reading comprehension. It could be seen by the quantitative data which showed the students were better in posttest than pretest.

\section{Conclusion}

From all the result above can be concluded that the implementation of extensive reading give positive effect on students' motivation and achievement of grade tenth in one of Senoir high schools in Surabaya. The increasement of students' motivation showed from the observation, while the improvement of students' reading comprehension explained from the mean pre and post-test. The paired t-test also indicated that the implementation of extensive reading significantly intensified students' reading achievement.

\section{References}

Anderson, N. (2003). Practical English Language Teaching First Edition. Singapore: McGrawHill.

Bamford, J., \& Day, R. R. (2003). Extensive Reading Activities for Teaching Language. Cambridge: Cambridge University Press. 
Day, R. R. (2015). Extending Extensive Reading. ISSN 1539-0578, Volume 27, No.2, pp. 294301.

Ferdila, R. (2014). The Use of Extensive Reading in Teaching Reading. Journal of English and Education, pp. 68-80.

Hidayat, N. (2016). November 2016, 2016 Published: 19. Journal of Educators Society, 1(October),95-104.

Iwahori, Y. (2008). Developing reading fluency: A study of extensive reading in EFL. ISSN 15390578, pp. 70-91.

Meng, F. (2009). Developing Students' Reading Ability Through Extensive Reading. CCSE , Volume 2, No.2.

Mikeladze, T. (2014). Extensive Reading. pp. 1-70.

Morgado, N. F. (2009). Extensive Reading: Students' Performance and Perception. The Reading Matrix , pp. 31-43.

Prowse, P. (2002). Top Ten Principles for Teaching Extensive Reading: A Respon. ISSN 1539-0578 , Volume 14, No.2. 